\title{
Morphological variation of Allagoptera arenaria (Gomes) Kuntze, 1891 (Arecaceae) in continental and insular environment
}

\section{Ana Paula Jejesky de Oliveira* and Amanda Toledo Lourenço}

Ecology and Ecosystems Postgraduate Program. Vila Velha University. Vila Velha-ES, Brazil (CEP 29102-920). *Email: anapaulaoliveira799@yahoo.com.br.

\begin{abstract}
Various evolutionary and ecological aspects in isolated environments, such as islands, associated with speciation events, play a role in biological diversification. In this sense, the morphological characteristics of Allagoptera arenaria (Gomes) Kuntze, 1891 (Arecaceae) species on mainland and island were evaluated to detect possible differences that reflect adaptive responses to the island environment. This study provides the first demonstration on the relationship of morphological differences of $A$. arenaria species. Height, perimeter, and total number of fruits and flowers from each plant were used for nonparametric analysis using the Mann-Whitney $U$ test. The plants of the island did not show evident patterns in the different morphological characteristics of the plants of the continent. It is believed that the species may not be a good representative of adaptive evidence for islands.
\end{abstract}

Keywords: Island biogeography; Guriri; Morphology; Speciation; Seashore palm; Plant.

\section{Introduction}

Considering evolutionary aspects subject to isolation patterns, immigration and extinction rates and environmental patterns, they are targets for studies of island biogeography (Petrocchi et al., 2013). Some ecological factors like the
Received

Octuber 30, 2019

Accepted

December 21, 2019

Released

December 31, 2019

Full Text Article

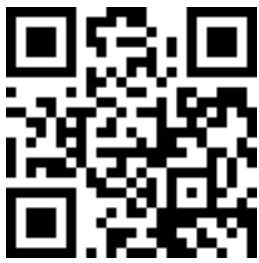

ORCID

D) 0000-0003-2933-9764 Ana Paula Jejesky de Oliveira

(1) 0000-0003-0877-3270

Amanda Toledo

Lourenço reduced size and isolation of the islands, scarcity of resources, decrease of competition interspecific, lack of predators and restrictions to dispersal over long distances are closely linked to the distribution and evolution of populations to islands (Lomolino, 2005). 
Species of isolated islands often differ dramatically in size in comparison with their relatives on the continent, for reasons that are little understood. Although decades of research have sought to better understand the changes in size and other characteristics in animals that occur on islands, very few studies have investigated the changes of size in plants island (Burns, 2016).

There are some hypotheses for understanding the morphological variation. In the event of a variation of the niche is expected that the morphological variation overlaps positively with the amplitude of the niche (Van Valen, 1965). Another prediction under this hypothesis is that the morphological variation increases on islands (Meiri et al., 2005). The populations of these islands face less species competitors, and the increase of morphological variation may facilitate the occupation of the space of the niche available (Grant, 1965; Lomolino, 2005). Alternatively, you can become less pronounced in the islands, contrary to the predictions of the hypothesis of variation of the niche. This can result in the reduction of the diversity of habitats, abundance of resources, gene flow, or of the fluctuations of the cycle of taxa (Ricklefs and Bermingham, 2002; Meiri et al., 2005).

In this sense, we aimed to compare attributes morphological Allagoptera arenaria (Gomes) Kuntze, 1891 (Arecaceae) present on the island and the mainland, aiming to detect possible differences that reflect adaptive responses to the environment of the island.

\section{Material and methods}

\section{Area of study}

The study was developed in the Area of Environmental Protection of Setiba (APA Setiba), created by Decree 3.747-N/1994, which is located between the northeast region of the Municipality of Guarapari and the extreme south of the Municipality of Vila Velha $\left(20^{\circ} 35^{\prime} 04^{\prime \prime} \mathrm{S}\right.$ and $\left.40^{\circ} 25^{\prime} 27^{\prime \prime} \mathrm{W}\right)$ around the Parque Estadual Paulo César Vinha (PEPCV), cut in half by the Highway of the Sun. The APA Setiba presents 12.960 ha of territorial extension, where, 7.500 ha are in terrestrial environment, and 5.460 ha in the marine environment (archipelago of Three Islands, comprising the largest APA State. The APA Setiba works as a buffer zone to the Parque Estadual Paulo Cesar Vinha (PEPCV).

\section{study}

\section{Characterization of the kind of}

Allagoptera arenaria (Gomes) Kuntze, 1891 is a palm in the Family Arecaceae, with a maximum height of approximately $1.5 \mathrm{~m}$ and $2.0 \mathrm{~m}$ diameter cup. It is a kind monoic and distributes on the plain of Brazil, occurring from Sergipe to Paraná, in the dunes or areas of restinga, in soils, extremely sandy soils (Lorenzi et al., 2004). It is one of the main facilitators in the succession of thickets in the formation bushy of Clusia (Zaluar and Scarano, 2000), since it germinates easily under natural conditions, and accumulates organic matter in the soil, allowing the establishment of other species (Menezes and Araujo, 2000).

\section{Collection and analysis}

The collection of the data was performed in species of the mainland and of the island in two days in the month of April of 2018. Each plant adult reproductive stage of the species and Allagoptera arenaria were marked as to its location by GPS, and measures such as the height and circumference total was checked by means of a measuring tape. Information about the number of fruiting and number of flowering were also recorded.

To check the normality of the data, it was used the Shapiro-Wilk Test. The assessment of the morphological variation and amount of fruiting of the 

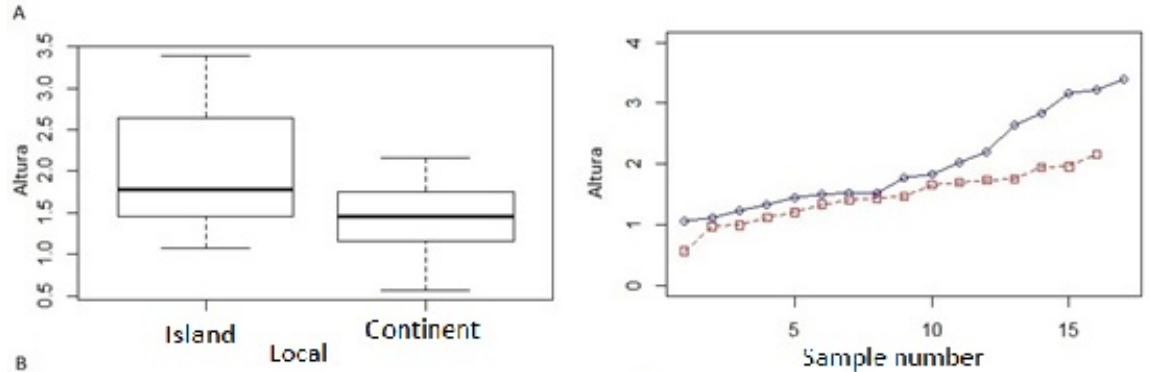

Continent
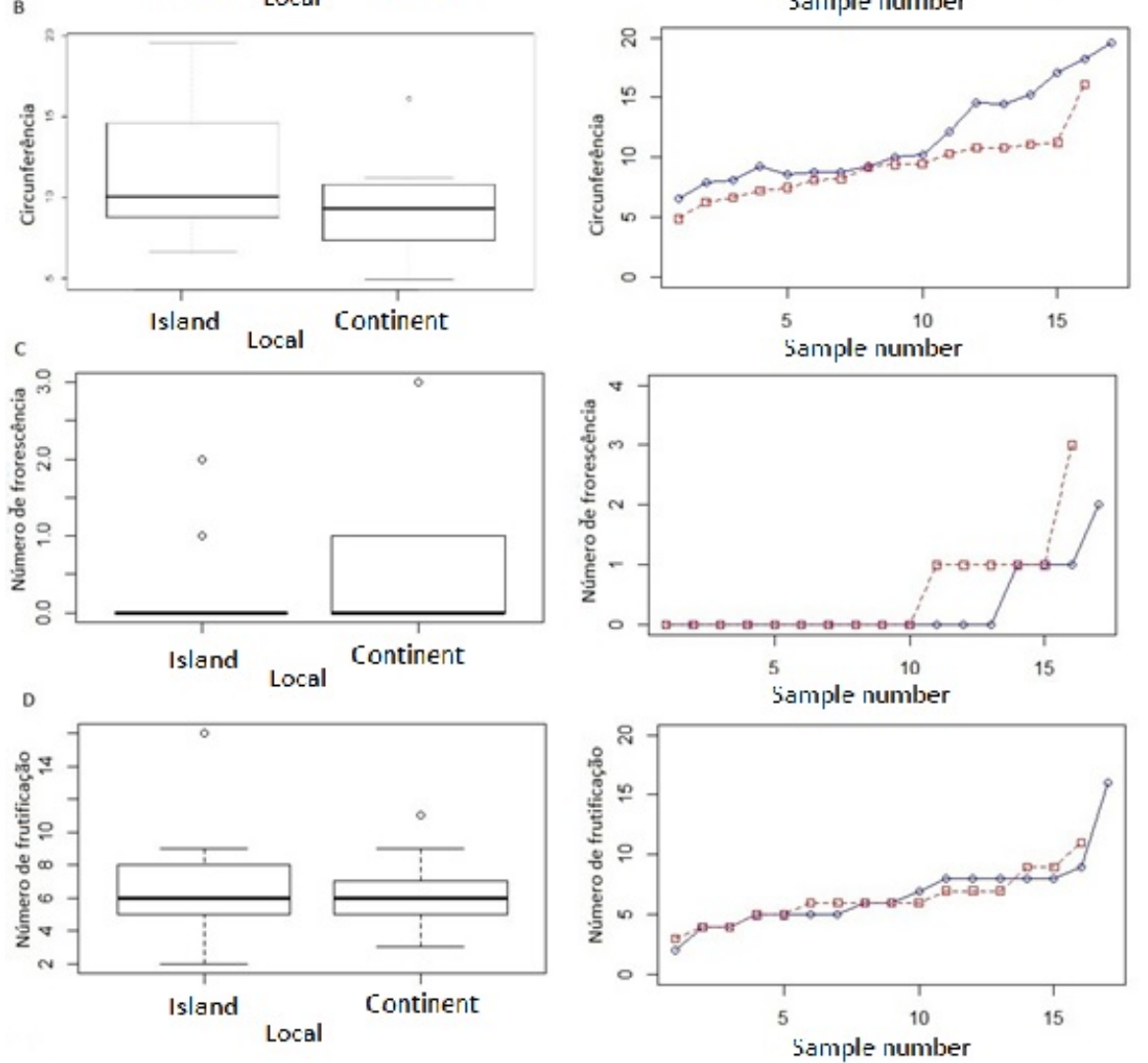

Figure 1. Graphical representations of morphological data of Allagoptera arenaria environment of the islands and mainland. In A represents the data of height of the individuals of the island and the mainland with a slight indication of plants island the largest. In B describes the data of the circumference practically equal in the two environments. In C describes the data of flowering of individuals in the two environments. In the D informs the data of fruiting, mature or not in plants the insular and continental.

environment of the islands and the continental was used the non-parametric test $\mathrm{U}$ of Mann-Whitney Test.

\section{Results}

Using the Shapiro-Wilk Test, it was found the abnormality of the data. 
With the U Test of Mann-Whitney test, the mature plants on the mainland and on the island did not show any significant effect on morphological characteristics (Table 1).

Table 1. Results of the U Test of Mann-Whitney for morphological data of Allagoptera arenaria environment of the islands and continental.

\begin{tabular}{|c|c|c|c|c|}
\hline \multicolumn{5}{|c|}{ U test: Environment in insular and continental } \\
\hline Height x Local & $\begin{array}{l}\text { Circumference } \mathrm{x} \\
\text { Local }\end{array}$ & Fruiting x Local & $\begin{array}{l}\text { Flowering } \mathrm{x} \\
\text { Local }\end{array}$ & Latitude x Local \\
\hline $\begin{array}{c}\mathrm{U}=189.5 \\
\mathrm{p} \text {-value }= \\
0.0562\end{array}$ & $\begin{array}{c}\mathrm{U}=177.5 \\
\mathrm{p} \text {-value }=0.1396\end{array}$ & $\begin{array}{c}\mathrm{U}=141.5 \\
\mathrm{p} \text {-value= } \\
0.8554\end{array}$ & $\begin{array}{c}\mathrm{U}=117.5 \\
\mathrm{p} \text {-value }=0.4204\end{array}$ & $\begin{array}{c}\mathrm{U}=257 \\
\mathrm{p} \text {-value }=1.172 \mathrm{e}- \\
06\end{array}$ \\
\hline
\end{tabular}

It was found that plants of the island did not differ consistently in measurements of height, circumference, number of fruiting or flowering and as the latitude between the plants of Allagoptera arenaria when compared to the plants of the same species on the mainland (Figure 1).

\section{Discussion}

Many processes are hypothesized to promote change in taxa island. The competition for limited resources might promote morphological changes (Blondel, 2000; Millien, 2004), as well as climatic differences (Clegg and Owens, 2002; Millien and Damuth, 2004), changes in resource availability (Boyer and Jetz, 2010; McNab, 2010) and different rates of evolutionary change on the island (Anderson and Handley, 2004). The sizes of the leaves, stems, and seeds, for example, can evolve in a coordinated fashion (Corner, 1949).

The islands usually support fewer species than areas of similar size on the mainland (MacArthur and Wilson 2001; Whittaker and Fernández-Palacios, 2007). However, Darwin (1859) had already raised the hypothesis that the increase of competition intraspecific should favor the evolution of plants on the islands. The population densities of the species in the island are also much higher than that of the mainland (MacArthur et al., 1972; Rodda and DeanBradley, 2002). However, the results of this study did not indicate significant differences to confirm these hypotheses (Figure 1).

$$
\begin{aligned}
& \text { According to Cody and Overton } \\
& \text { (1996), morphological changes }
\end{aligned}
$$
associated with the reduced ability of dispersal in plants island can evolve very quickly, perhaps in less than a decade. However, assuming the results are not significant for the data of Allagoptera arenaria, they also do not express the hypothesis of Cody and Overton (1996). It is believed that the sample number of individuals of the island may be small or even the evolutionary time can be short to highlight possible differences.

In his study of island evolution, Carlquist (1974) speculated that changes in the height of island plants could result from differences in the types of habitat that plants can occupy on islands. Thus, the decline or increase in plant height in island plants may result from structural changes in their preferred habitat. However, the population of Three Islands showed no significant differences. In this sense, it also becomes opposed to the variation hypothesis proposed by Meiri 
et al. (2005), supported by the niche variation hypothesis (Van Valen, 1965) because in this study it was not predicted that the morphological variability is increased in the islands. This may indicate that the habitats of the Three Islands occupied by the species do not present big differences if buying with mainland habitats, not reflecting in morphological differences of adaptations for the variables evaluated in this research.

\section{Conclusion}

This study provides the first demonstration of the relationship of differences morphological of plants of the species and Allagoptera arenaria in continental and insular environment. But various aspects of this study justify a cautious approach to extrapolating the results to other species. First, the focus species of the study is comprehensive and can be found in a wide range of latitudes and the analyzes presented were restricted to only two populations. Second, this study focused on a single species, which may cannot be a good representative of adaptive evidence for islands in relation to the morphological characteristics.

\section{Acknowledgments}

The research of authours is supported by the Espírito Santo Research and Innovation Support Foundation.

\section{Conflicts of interest}

Authors declare that they have no conflict of interests.

\section{References}

Anderson, R. P.; Handley, C. O. Dwarfism in insular sloths: Biogeography, selection, and evolutionary rate. Evolution, v. 56, no. 5, p. 1045-1058, 2002. https://doi.org/ 10.1111/j.0014-3820.2002.tb01415.x
Blondel, J. Evolution and ecology of birds on islands: Trends and prospects. Vie et Milieu, v. 50, no. 4, p. 205-220, 2000.

Boyer, A. G.; Jetz, W. Biogeography of body size in Pacific island birds. Ecography, v. 33, no. 2, p. 369-379, 2010. https://doi.org/ 10.1111/j.1600-0587.2010.06315.x

Burns, K. C. Size changes in island plants: Independent trait evolution in Alyxia ruscifolia (Apocynaceae) on Lord Howe Island. Biological Journal of the Linnean Society, v. 119, no. 4, p. 847-855, 2016. https://doi.org/10.1111/bij.12851

Carlquist, S. Island biology. Columbia: Columbia University Press, 1974.

Clegg, S. M.; Owens, P. F. The 'island rule' in birds: Medium body size and its ecological explanation. Proceedings of the Royal Society of London. Series B: Biological Sciences, v. 269 , no. 1498 , p. 1359-1365, 2002 . https://doi.org/10.1098/rspb. 2002.2024

Cody, M. L.; Overton M. C. J. Short-term evolution of reduced dispersal in island plant populations. Journal of Ecology, v. 84, no. 1, p. 53-61, 1996.

Corner, E. J. H. The Durian Theory or the origin of the modern tree. Annals of Botany, v. 13, no. 52, p. 367-414, 1949. https://doi.org/10.1093/oxfordjournals.aob. a083225

Darwin C. On the origin of species by means of natural selection. London: J. Murray, 1859.

Grant, P. R. The adaptive significance of some size trends in island birds. Evolution, v. 19, no. 3, p. 355-367, 1965. https://doi.org/ 10.1111/j.1558-5646.1965.tb01727.x

Lomolino, M. V. Body size evolution in insular vertebrates: Generality of the island rule. Journal of Biogeography, v. 32, no. 10, p. 1683-1699, 2005. https://doi.org/ 10.1111/j.1365-2699.2005.01314.x

Lorenzi, H.; Souza, H. D.; Costa, J. D. M.; Cerqueira, L. D.; Ferreira, E. Palmeiras brasileiras e exóticas cultivadas. Nova Odessa: Instituto Plantarum, 2004.

MacArthur, R. H.; Diamond, J. M.; Karr, J. R. Density compensation in island faunas. Ecology, v. 53, no. 2, p. 330-342, 1972. https://doi.org/10.2307/1934090 
MacArthur, R. H.; Wilson, E. O. The theory of island biogeography. Princeton: Princeton University Press, 1967.

McNab, B. K. Geographic and temporal correlations of mammalian size reconsidered: A resource rule. Oecologia, v. 164, no. 1, p. 13-23, 2010. https://doi.org/ $10.1007 / \mathrm{s} 00442-010-1621-5$

Meiri, S.; Dayan, T.; Simberloff, D. Variability and sexual size dimorphism in carnivores: Testing the niche variation hypothesis. Ecology, v. 86, no. 6, p. 1432-1440, 2005. https://doi.org/10.1890/04-1503

Menezes, L. D.; Araujo, D. D. Variação da biomassa aérea de Allagoptera arenaria (Gomes) 0. Kuntze (Arecaceae) em uma comunidade arbustiva de Palmae na Restinga de Marambaia, RJ. Revista Brasileira de Biologia, v. 60, no. 1, p. 147-157, 2000. https://doi.org/10.1590/S0034-7108 2000000100017

Millien, V. Relative effects of climate change, isolation and competition on body-size evolution in the Japanese field mouse, Apodemus argenteus. Journal of Biogeography, v. 31, no. 8, p. 1267-1276, 2004. https://doi.org/10.1111/j.1365-2699. 2004.01119.x

Millien, V.; Damuth, J. Climate change and size evolution in an island rodent species: New perspectives on the island rule. Evolution, v. 58, no. $6, \quad$ p. $1353-1360,2004$. https://doi.org/10.1111/j.0014-3820. 2004.tb01713.x

Petrocchi,S. A.; Simonelli, M.; Co, W. L. D. O. Influência biogeográfica na morfologia de diásporos de três espécies insulares e continentais ocorrentes em Setiba, ES. Revista Científica Faesa, v. 9, no. 1, p. 119127, 2013.

Ricklefs, R. E.; Bermingham, E. The concept of the taxon cycle in biogeography. Global Ecology and Biogeography, v. 11, no. 5, p. 353-361, 2002. https://doi.org/ 10.1046/j.1466-822x.2002.00300.x

Rodda, G. H.; Dean-Bradley, K. Excess density compensation of island herpetofaunal assemblages. Journal of Biogeography, v. 29 , no. $5 / 6$, p. $623-632, \quad 2002$. https://doi.org/10.1046/j.1365-2699. 2002.00711.x

Van Valen, L. Morphological variation and width of ecological niche. The American Naturalist, v. 99, no. 908, p. 377-390, 1965.

Whittaker, R. J.; Fernández-Palacios, J. M. Island Biogeography: Ecology, Evolution, and conservation. Oxford: Oxford University Press, 2007.

Zaluar, H. L. T.; Scarano, F. Facilitação em restingas de moitas: um século de buscas por espécies focais. In: Esteves, F. A.; Lacerda, L. D. (Eds.). Ecologia de restingas e lagoas costeiras. Rio de Janeiro: Nupem-UFRJ, 2000. p. 3-23. 